\title{
Effectiveness of physical activity and dietary interventions in South Asian populations:
}

\author{
a systematic review
}

\begin{abstract}
\section{Background}

Physical activity and dietary change interventions can prevent or delay a range of chronic disease. Little is known in primary care about their effectiveness in South Asian populations, who are often at higher risk of developing such diseases.

\section{Aim}

To assess evidence for effectiveness of primary care based physical activity and dietary interventions in South Asian populations, and identify methods to inform future intervention development.

\section{Design}

Systematic review.

\section{Method}

Intervention studies conducted in developed countries that reported data for South Asian adults were sought by searching electronic databases, trial registries, and conference proceedings. Following wider screening of titles and abstracts, 119 full articles were reviewed.

\section{Results}

Of the 119 articles, four studies met the inclusion criteria and evaluated community-based interventions with South Asian individuals. Methodological quality was poor overall. Interventions appeared generally effective in promoting a decrease in weight, with some positive changes in blood pressure and biochemical outcomes, such as cholesterol. There was limited evidence for effects on behaviour. Theoretical frameworks were not identified and evidence on attitudinal or knowledge-based outcomes was sparse. The inclusion of individual feedback and community workers in communities of deprivation appeared important to the acceptability of the interventions. Information distinguishable for South Asian individuals within intervention studies of general populations was lacking.

\section{Conclusion}

Physical activity and dietary interventions with South Asian populations show modest promise

\section{INTRODUCTION}

In developed countries, people of South Asian origin who are historically immigrant lincluding those of Indian, Pakistani, Bangladeshi, and Sri Lankan ancestral origins) have markedly higher and earlier mortality and morbidity from coronary heart disease (CHD) and type 2 diabetes, as well as their complications, than the general population. ${ }^{1-3}$ These contribute to extensive disability and suffering, as well as significant societal costs. For primary care, the greatest opportunity to address the personal and societal burden of such chronic disease is to prevent development of the disease or delay its onset in those, often socially disadvantaged, communities that are at highest risk and need. ${ }^{4}$

Although genetic factors contribute, lifestyle features strongly in the development of a range of chronic diseases. ${ }^{5}$ Well-documented risk factors for cardiovascular disease, diabetes, and cancer include physical inactivity, a diet that is high in fat and sugar, and obesity. 3,6,7 A significant association is found between cardiovascular-protective behaviours and lower risk of all-cause and cardiovascular mortality on a national scale. ${ }^{8}$ Large international trials of intensive physical activity and dietary interventions have demonstrated long-term reductions in the development of type 2 diabetes for adults at higher risk. ${ }^{9.10}$ Several reviews on the effects of diet and exercise on the incidence of CHD and type 2 diabetes have emphasised their importance in the primary and secondary prevention of disease. ${ }^{11-13}$
\end{abstract} but, given the paucity of controlled evaluations or use of objective measures, outcomes are difficult to interpret. Potential insights may be missed if experience concerning South Asian groups within studies is not reported. Further development of culturally appropriate interventions that are theoretically informed and assessed in experimental designs are required.

\section{Keywords}

community; dietary change, physical activity;

primary care; South Asian; systematic review.
J Chapman, PhD, research fellow; N Qureshi

professor, Division of Primary Care, University of Nottingham, Nottingham.

\section{Address for correspondence}

Joe Kai, Division of Primary Care, University of

Nottingham, Tower Building, University Park,

Nottingham, NG7 2RD.
DM, MRCGP, professor; J Kai, MD, FRCGP
With South Asian populations identified as less physically active than the general population, ${ }^{14,15}$ alongside growing concern about child and adult obesity, ${ }^{16}$ culturally appropriate and effective interventions in this high-risk group are urgently needed. ${ }^{17}$ However, little is known about relevant experience of such interventions with South Asian populations. This study aimed to systematically review current evidence to address two research questions:

- Can community or primary care based interventions targeting physical activity and/or dietary change improve health outcomes in people of South Asian origin in developed countries?

- Can culturally appropriate methods and theoretical models be identified from eligible studies to inform the development and delivery of future interventions?

\section{METHOD}

Study eligibility criteria were any community or primary care based intervention study conducted in a developed country that quantitatively evaluated the effectiveness of a physical activity and/or dietary change intervention in adult South Asian communities of people who were historically immigrant, or described inclusion of the latter in their samples and reported data identifiable for South Asian individuals. The search aimed to identify both randomised and non-randomised controlled studies, the latter including before and after, betweengroup designs. The search was limited to the English language.

E-mail: joe.kaidnottingham.ac.uk Submitted: 23 April 2012; Editor's response: 26 June 2012; final acceptance: 21 August 2012. (CBritish Journal of General Practice

This is the full-length article lpublished online 28 Jan 2013) of an abridged version published in print. Cite this article as: $\mathbf{B r} \mathbf{J}$ Gen Pract 2013; DOI: 10.3399/bjgp13X663064 


\section{How this fits in}

Evidence for the impact of interventions promoting dietary change and physical activity is strong, particularly for diabetes, but less is known about their effectiveness in South Asian populations at high risk of developing chronic diseases. This systematic review suggests there is modest evidence that interventions with people of South Asian origin may improve weight loss, blood pressure, and blood lipid profiles, although there is little evidence for facilitating change in behaviour or knowledge. Communitybased interventions involving bilingual link workers and using individual feedback, appear promising, especially within South Asian communities that are socio-educationally disadvantaged. The development of culturally appropriate interventions that are theoretically based and evaluated in high-quality experimental research is still needed to achieve effective health promotion in this high-risk group.

The following databases were searched from inception to January 2011: MEDLINE ${ }^{\circledR}$, embase, CINAHL ${ }^{\circledR}$, PsycINFO, Cochrane Database of Systematic Reviews, and DARE. Search strategies were designed for each database. The MEDLINE search strategy was developed using existing Cochrane search strategies and peer-reviewed by an information scientist (Box 1). Supplementary searches of online trial registries and conference proceedingswerealso conducted. Two reviewers independently inspected titles and abstracts of identified papers. The data extraction form was developed by two individuals, who independently reviewed the full-text articles of eligible studies; data extraction was undertaken by a third reviewer and the details were cross-checked by the first two individuals. Any disagreement on inclusion or data entry was resolved by consensus discussion.

From eligible studies, all effects of physical activity and dietary interventions were categorised into primary clinical outcomes and secondary outcomes of behaviour and psychological/knowledge-based change, which are meaningful in explaining clinical endpoints. ${ }^{18}$ Data were extracted in terms of the percentage of change from baseline to follow-up, and presented with the actual baseline value and level of statistical significance where available. Qualitative data on intervention acceptability were also extracted where available. The methodological quality of the studies was assessed using a validated quality index, ${ }^{19}$ based on the reporting of findings, validity, the extent of bias in measurement and outcome, and selection bias.

\section{RESULTS}

\section{Study characteristics and quality}

\section{assessment}

The flow of studies through the stages of the systematic review is shown in Figure 1. Data distinguishable for South Asian individuals who were historically immigrant and were, or may have been, included in the samples of many studies was lacking. In total, only four studies were included in the final review.

Details of the study characteristics and interventions are described in Table 1. Due to the small number of studies and considerable heterogeneity in intervention type, assessment, and outcome measures, meta-analyses were not feasible and a narrative synthesis was performed. ${ }^{20}$ The four studies included physical activity and/ or dietary change as part of one-to-one and/or group educational interventions for CHD risk and/or diabetes, involving health visitors, bilingual link workers, or dietitians in community settings. ${ }^{21-24}$

All studies were uncontrolled beforeand-after designs, except one randomised controlled trial. ${ }^{24}$ No studies reported using theoretical models to inform interventions, though one study ${ }^{21}$ measured participants' stage of change. ${ }^{25}$ Reported methodological quality was generally poor, with total scores ranging from $41 \%$ to $56 \%{ }^{19}$ (full data available from authors). The number of participants varied from $13^{23}$ to $201,{ }^{24}$ involving people who were largely from South Asian communities; however, detailed descriptors beyond ethnicity or, in one study, education, were lacking. For reporting quality, higher scores were gained for adequately describing study aims, interventions, and participants, but only three of the four studies clearly described the main findings. ${ }^{21-23}$ Two studies reported exact significance levels for the main outcomes ${ }^{21,22}$ and one reported a samplesize calculation. ${ }^{24}$ External and internal validity and bias scores were low, with only one study reporting reliable compliance with the intervention. ${ }^{24}$ One study failed to score on the use of accurate, valid, and reliable main-outcome measures ${ }^{24}$ and reliability of secondary measures was poor. No studies adjusted for confounding in analyses, or reported on potential adverse effects, and only one provided a comparison group. ${ }^{24}$ 


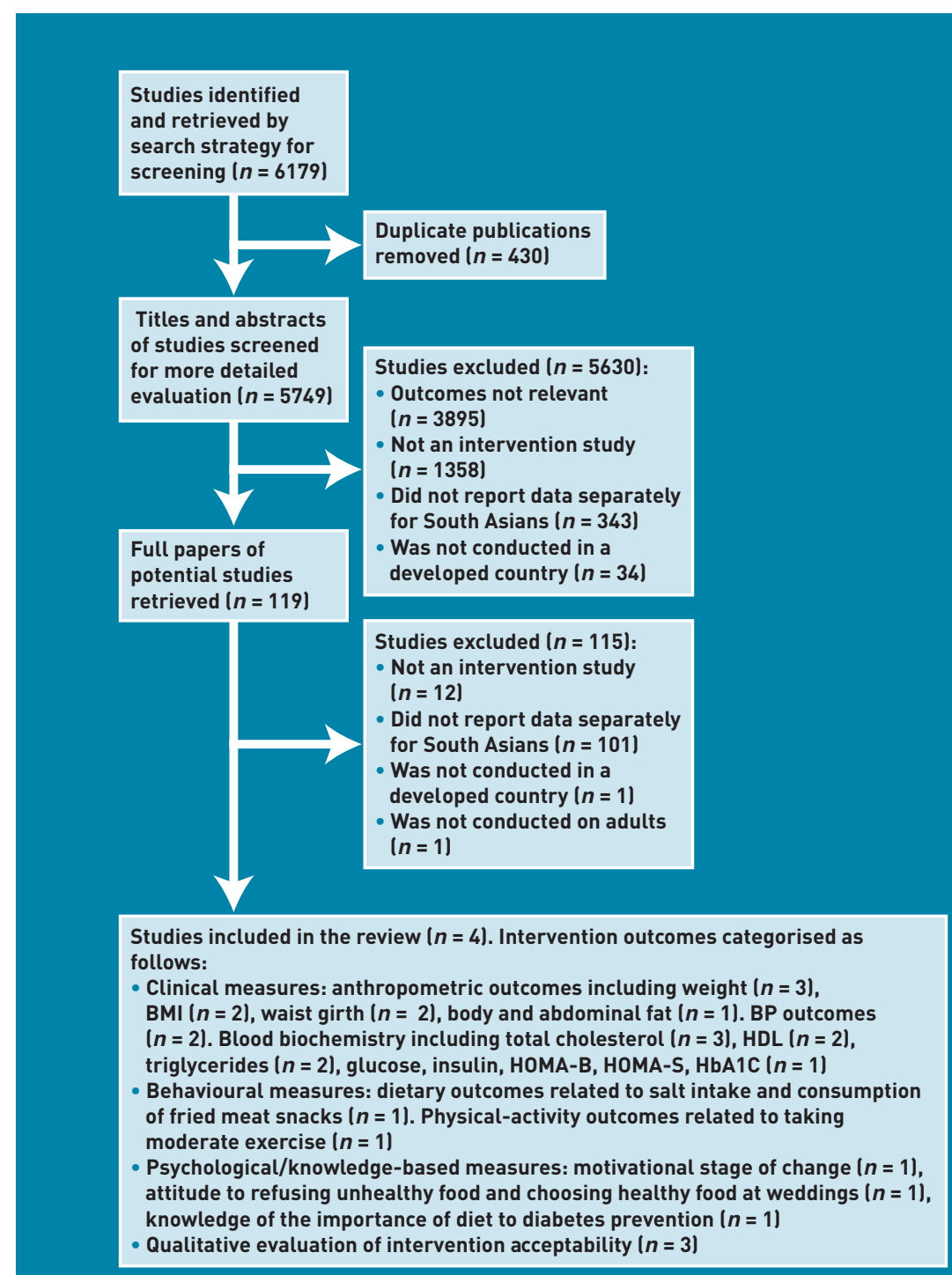

$B M I=$ body mass index. $B P=$ blood pressure. $H b A 1 c=$ glycosylated haemoglobin type A1c. HDL = high-density lipoprotein. HOMA-B = homeostatic model assessment of $\beta$-cell function. HOMA-S = homeostatic model assessment of insulin sensitivity.

Figure 1. Flow chart for studies through stages of systematic review.

\section{Intervention effects}

Clinical outcomes. The clinical impacts of the interventions are summarised in Table 2. All four studies reported clinical outcomes, including changes to anthropometric measures, blood pressure, and/or blood biochemistry. All studies measuring changes in weight demonstrated a reduction in kilogrammes from baseline to follow-up, ranging from a $0.9 \%$ reduction over $6-12$ months $^{21}$ to $3.4 \%$ at 17 months. ${ }^{23}$ Waist girth in centimetres showed small percentage decreases of $0.6^{21}$ and 2.1,22 and reductions in body and abdominal fat were also found. ${ }^{22}$ However, all reductions in weight, waist girth, and body and abdominal fat were significant for males only in one community-based, group-education intervention. ${ }^{22}$

One study reported significant reductions in systolic blood pressure of $2.8 \%{ }^{21}$ and two studies reported reductions in mean diastolic blood pressure of $3.9 \% 21$ and $3.9 \% 22$ (females only). Measures of blood biochemistry showed mixed results. Significant positive impacts on cholesterol $(-3.7 \% \text { over } 6-12 \text { months })^{21}$ were reported in one of three studies; increases in high-density lipoprotein were reported in another $19.5 \%$ females only, increases in males also approaching significance), ${ }^{22}$ and significant decreases in triglyceride levels $(13.3 \%)^{21}$ were found in one of two studies. No significant changes were reported in glucose, insulin, homeostatic model assessment of $\beta$-cell function (HOMA-B), homeostatic model assessment of insulin sensitivity (HOMA-S), or glycosylated haemoglobin type A1c (HbA1c).

Behavioural outcomes. Self-reported changes to dietary behaviour and physical activity were measured in one study ${ }^{21}$ (Table 3). Males and females reported significant improvements in salt intake and consumption of fried meat snacks following a CHD-prevention service. ${ }^{21}$ In relation to physical activity, an average of $49 \%$ of participants reported taking more moderate exercise ldefined as physical activity that makes one out of breath but not sweaty') 6-12 months after intervention. ${ }^{21}$ Another study discussed specific dietary changes, such as increases in fish intake and cereal, following group activity and dietary-education sessions, but no data were reported from these measures. ${ }^{22}$

Psychological and knowledge-based outcomes. Table 4 shows the psychological and knowledge-based impacts of the interventions. In total, 50\% of participants in one study showed an increase in the stage of change relating to motivation to address lifestyle behaviours after 6-12 months, in comparison with a decrease of $21 \%$ and $29 \%$ who stayed the same. ${ }^{21}$ With regard to attitude change, a single item about 'finding it hard to refuse food at social events' increased, and 'choosing correct food at weddings' showed a modest increase, but no significance data were reported. ${ }^{24}$

Little evidence was demonstrated for knowledge-based changes following the interventions. Single items asking if the participant agrees the importance of diet to diabetes prevention' and the percentage of people 'correctly identifying different food values' showed small increases after 6 

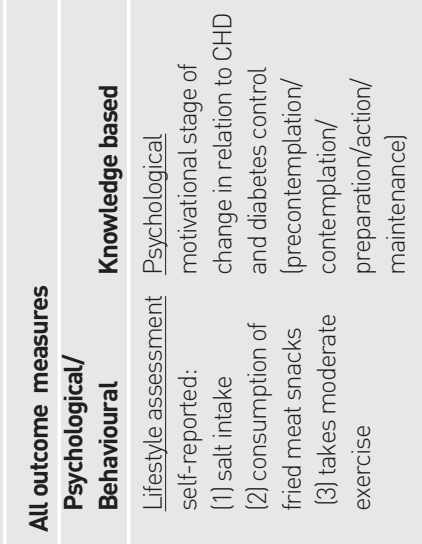

$\frac{\frac{\pi}{z}}{\frac{5}{z}}$
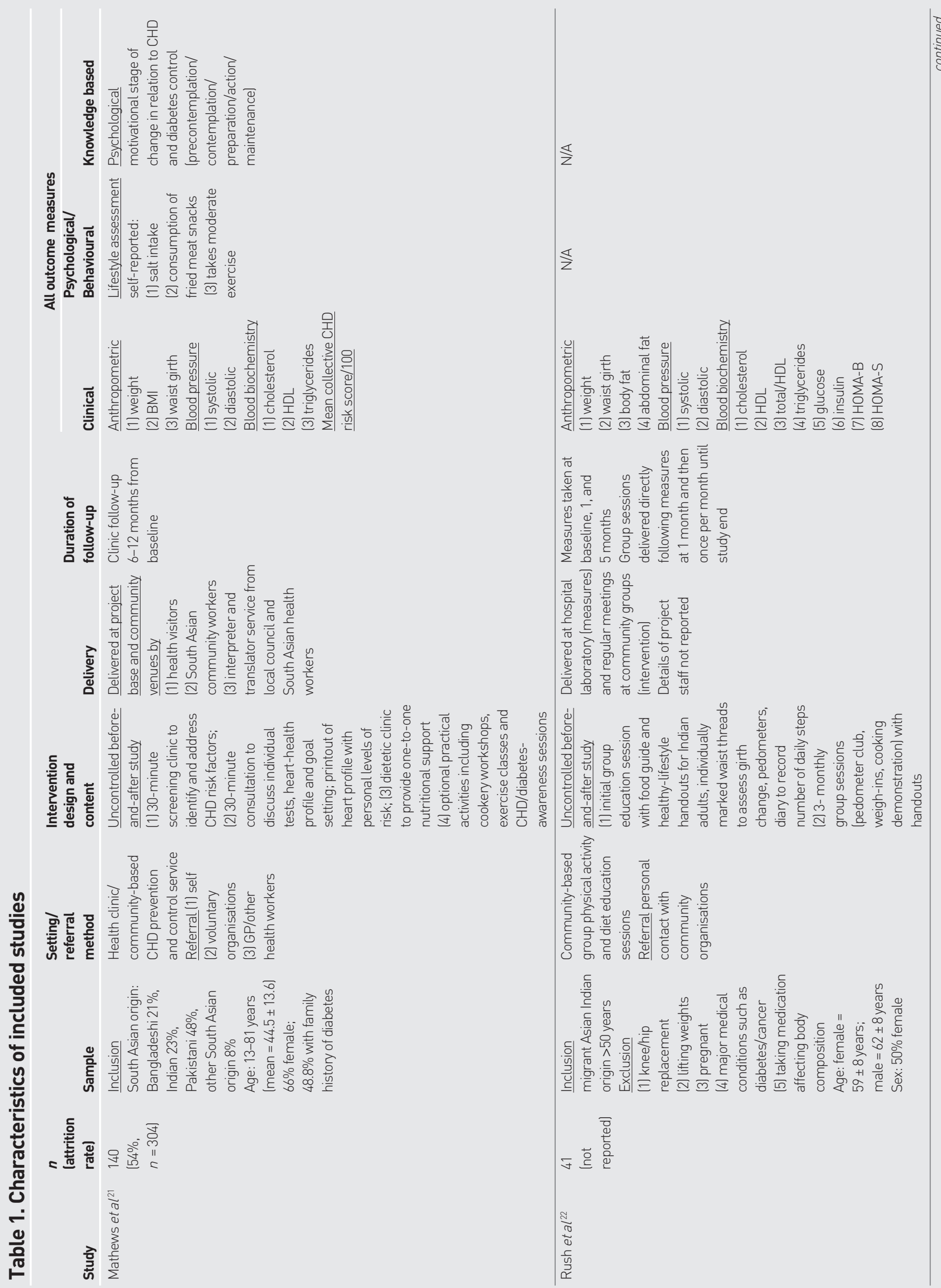


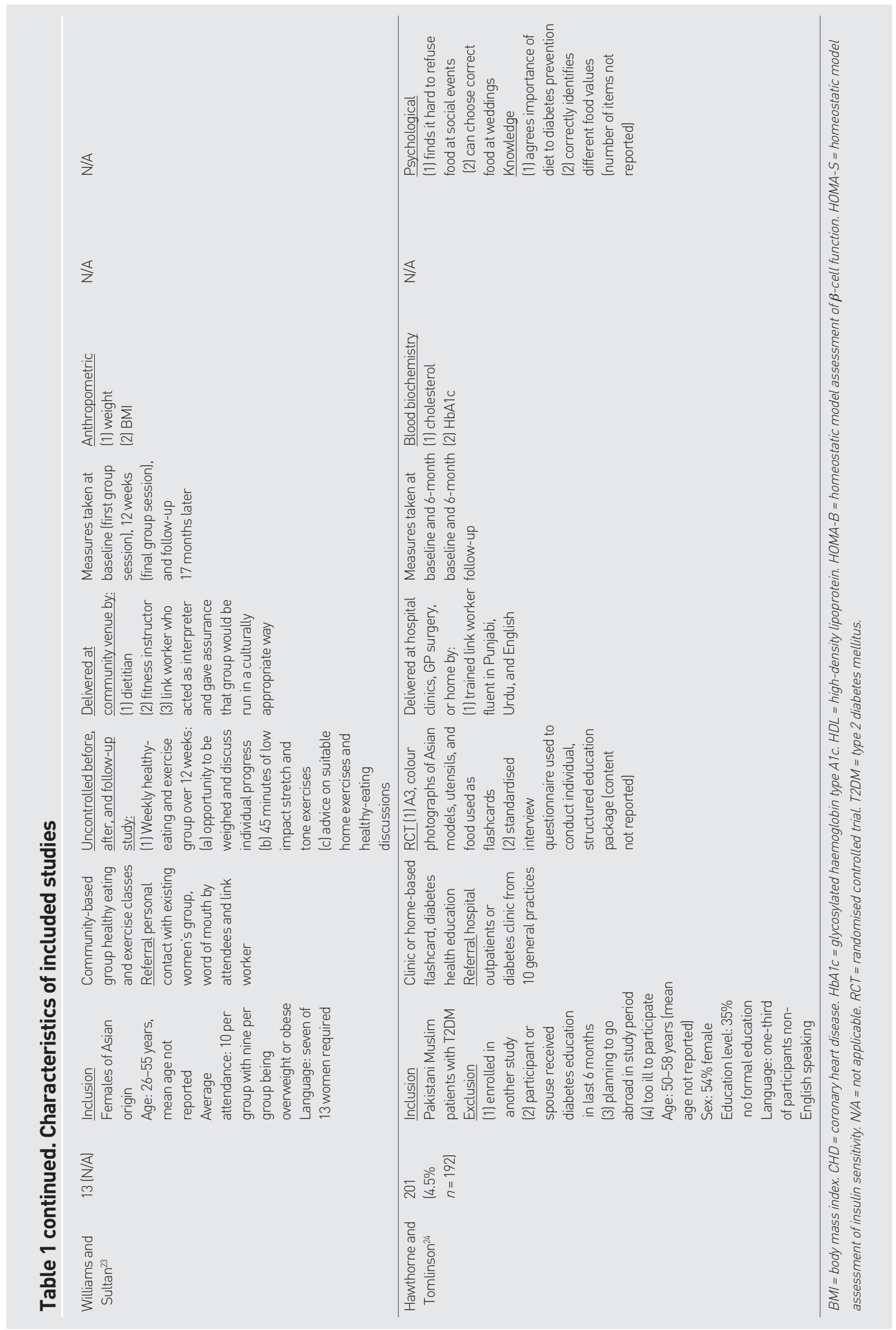


Table 2. Clinical outcomes of included studies

\begin{tabular}{|c|c|c|c|c|c|}
\hline Study & Intervention & $\begin{array}{l}\text { Outcome } \\
\text { measure }\end{array}$ & $\begin{array}{l}\text { Participants } \\
\text { analysed }\end{array}$ & Results & Notes \\
\hline Mathews et a ${ }^{21}$ & $\begin{array}{l}\text { Health clinic } \\
\text { one-to-one CHD } \\
\text { service with } \\
\text { optional } \\
\text { community activities }\end{array}$ & $\begin{array}{l}\frac{\text { Anthropometric }}{\text { (1) weight }(\mathrm{kg})} \\
\text { (2) BMI } \\
\text { (3) waist girth (cm) } \\
\text { Blood pressure } \\
\text { (1) systolic }(\mathrm{mmHg}) \\
\text { (2) diastolic }(\mathrm{mmHg} \text { ) } \\
\text { Blood biochemistry } \\
\text { (1) cholesterol (mmol/l) } \\
\text { (2) HDL } \\
\text { (3) triglycerides (mmol/l) } \\
\text { Mean collective CHD } \\
\text { risk score/100 }\end{array}$ & 140 & 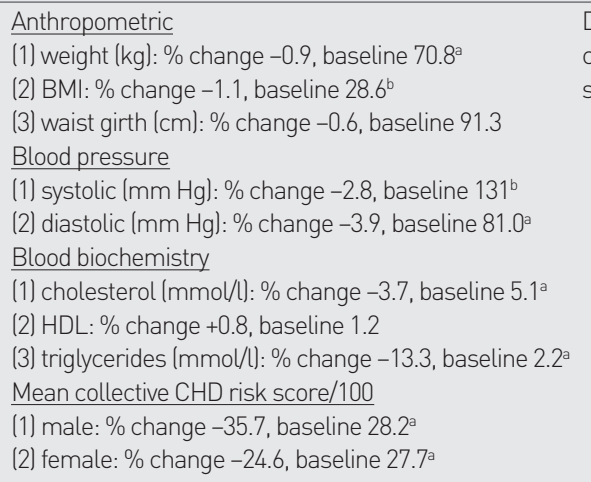 & $\begin{array}{l}\text { Details of mean } \\
\text { collective } \mathrm{CHD} \text { risk } \\
\text { score/100 not specified }\end{array}$ \\
\hline Rush et al ${ }^{22}$ & $\begin{array}{l}\text { Group physical- } \\
\text { activity and diet- } \\
\text { education sessions }\end{array}$ & $\begin{array}{l}\text { Anthropometric } \\
\text { (1) weight (kg) } \\
\text { (2) waist girth (cm) } \\
\text { (3) body fat (kg) } \\
\text { (4) body fat (\%) } \\
\text { (5) abdominal fat (kg) } \\
\text { (6) abdominal fat (\%) } \\
\text { Blood pressure } \\
\text { (1) systolic (mmHg) } \\
\text { (2) diastolic (mmHg) } \\
\text { Blood biochemistry } \\
\text { (1) cholesterol (mmol/l) } \\
\text { (2) HDL (mmol/l) } \\
\text { (3) total/HDL } \\
\text { (4) triglycerides (mmol/l) } \\
\text { (5) glucose (mmol/l) } \\
\text { (6) insulin (pmol/l) } \\
\text { (7) HOMA B (\%) } \\
\text { (8) HOMA S (\%) }\end{array}$ & $\begin{array}{l}20 \text { female } \\
21 \text { male }\end{array}$ & 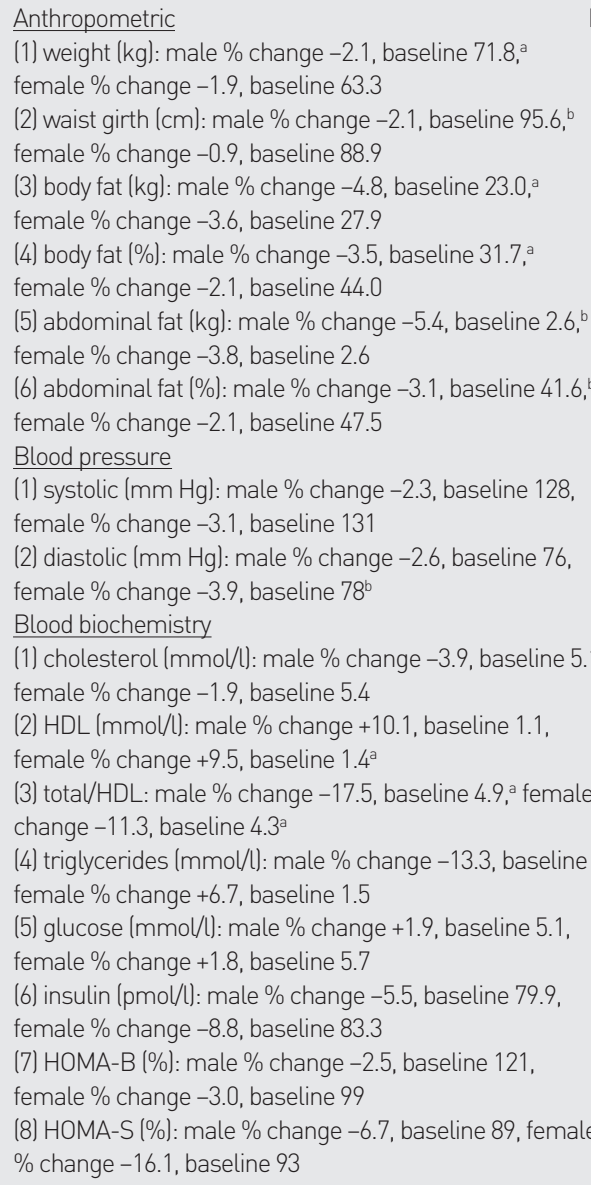 & $\begin{array}{l}\text { N/A } \\
\text { b.1, } \\
\text { b. } \\
\text { be } \% \\
\text { e 1.5, } \\
\text { le } \\
\end{array}$ \\
\hline Williams and Sultan ${ }^{23}$ & $\begin{array}{l}\text { Group healthy-eating } \\
\text { and exercise classes }\end{array}$ & $\begin{array}{l}\text { Anthropometric } \\
\text { (1) weight (kg) } \\
\text { (2) BMI }\end{array}$ & 13 & $\begin{array}{l}\text { Anthropometric } \\
\text { (1) Weight (kg): } \\
\text { (a) baseline to } 12 \text { months: } \% \text { change }-2.9 \text {, baseline } 77.3 \\
\text { (b) baseline to } 17 \text { months: \% change }-3.4 \text {, baseline } 77.3 \\
\text { (2) BMl: } \\
\text { (a) baseline to } 12 \text { months: \% change }-3.0 \text {, baseline } 31.9 \\
\text { (b) baseline to } 17 \text { months: \% change }-3.5 \text {, baseline } 31.9\end{array}$ & $\begin{array}{l}\text { Statistical tests and } \\
P \text {-values not reported }\end{array}$ \\
\hline $\begin{array}{l}\text { Hawthorne and } \\
\text { Tomlinson }^{24}\end{array}$ & $\begin{array}{l}\text { Flashcard one-to-one } \\
\text { diabetes health } \\
\text { education }\end{array}$ & $\begin{array}{l}\text { Blood biochemistry } \\
\text { (1) cholesterol (mmol/l) } \\
\text { (2) HbA1c (\%) }\end{array}$ & $\begin{array}{l}106 \\
\text { interventions } \\
86 \text { controls }\end{array}$ & $\begin{array}{l}\text { Blood biochemistry } \\
\text { (1) cholesterol (mmol/I): ANOVA-adjusted pre-post } \\
\text { difference in intervention group <0.1, baseline } 5.9 \\
\text { (2) HbA1c, \%: (a) ANOVA-adjusted pre-post difference } \\
\text { in intervention group -0.3, baseline } 8.4\end{array}$ & $P$-values not reported \\
\hline
\end{tabular}

${ }^{a} P<0.01 .{ }^{b} P<0.05 . A N O V A=$ analysis of variance. $B M l=$ body mass index. $C H D=$ coronary heart disease. $H b A 1 c=$ glycosylated haemoglobin type $A 1 c . H D L=$ high-density lipoprotein. HOMA-B = homeostatic model assessment of $\beta$-cell function. HOMA-S = homeostatic model assessment of insulin sensitivity. N/A = not applicable. 


\section{Table 3. Behavioural outcomes of relevant included studies}

\begin{tabular}{|c|c|c|c|c|c|c|}
\hline Study & Intervention & $\begin{array}{l}\text { Outcome } \\
\text { measure }\end{array}$ & $\begin{array}{l}\text { Participants } \\
\text { analysed }\end{array}$ & Results & Other analysis & Notes \\
\hline Mathews et al ${ }^{21}$ & $\begin{array}{l}\text { Health clinic } \\
\text { one-to-one CHD } \\
\text { service with } \\
\text { optional community } \\
\text { activities }\end{array}$ & $\begin{array}{l}\frac{\text { Lifestyle }}{\text { assessment }} \\
\text { (1) salt intake } \\
\text { (2) consumption } \\
\text { of fried meat snacks } \\
\text { (3) takes moderate } \\
\text { exercise }\end{array}$ & $\begin{array}{l}104 \text { female } \\
36 \text { male }\end{array}$ & $\begin{array}{l}\text { Lifestyle assessment } \\
\text { (1) Salt intake } \\
\text { (a) male \% showing improvement } 16.7(n=6) \text {, } \\
\text { male \% showing deterioration } 2.8(n=1)^{\mathrm{a}} \\
\text { (b) female \% showing improvement } 31.1(n=32) \text {, } \\
\text { female } \% \text { showing deterioration } 1.9(n=2)^{\mathrm{b}} \\
\text { (2) Consumption of fried meat snacks } \\
\text { (a) male \% showing improvement } 44.4(n=16) \text {, } \\
\text { male \% showing deterioration } 8.3(n=3)^{\mathrm{a}} \\
\text { (b) female \% showing improvement } 36.9(n=38) \text {, } \\
\text { female \% showing deterioration } 21.4(n=22)^{\mathrm{a}} \\
\text { (3) Takes moderate exercise } \\
\text { (a) male \% showing improvement } 52.8(n=19) \text {, } \\
\text { male \% showing deterioration } 5.6(n=2)^{\mathrm{b}} \\
\text { (b) female \% showing improvement } 45.2(n=47) \text {, } \\
\text { female \% showing deterioration } 14.6(n=15)^{\mathrm{b}}\end{array}$ & $N / A$ & $\begin{array}{l}\text { Actual pre- and post- } \\
\text { test values not reported }\end{array}$ \\
\hline Rush et al ${ }^{22}$ & $\begin{array}{l}\text { Group physical } \\
\text { activity and diet } \\
\text { education sessions }\end{array}$ & $\mathrm{N} / \mathrm{A}$ & $\begin{array}{l}20 \text { female } \\
21 \text { male }\end{array}$ & $\mathrm{N} / \mathrm{A}$ & $\begin{array}{l}\text { Pre-post change } \\
\text { to diet discussed } \\
\text { but no details of } \\
\text { measures, score } \\
\text { or statistics repo } \\
\text { (1) all participant } \\
\text { used healthier c } \\
\text { (2) more than } 90 \\
\text { more cereals an } \\
\text { removed skin frc } \\
\text { chicken } \\
\text { (3) three particip } \\
\text { increased fish in }\end{array}$ & $\begin{array}{l}\text { es } \\
\text { d, } \\
\text { es, } \\
\text { orted: } \\
\text { ts } \\
\text { ooking oil } \\
\text { \% ate } \\
\text { ad } \\
\text { om } \\
\text { ants } \\
\text { take }\end{array}$ \\
\hline
\end{tabular}

${ }^{a} P<0.05 .{ }^{b} P<0.01 . C H D=$ coronary heart disease. $N / A=$ not applicable.

months, but no significance levels were reported. ${ }^{24}$

Intervention acceptability. Three of the four studies presented data on the acceptability of programmes; ${ }^{21,23,24}$ these reported that interventions were positively valued and some participants felt empowered to control health issues following the programme. ${ }^{24}$ In one study, 69\% of women attending community healthy-eating and exercise classes said they would recommend them to friends, and attended for social reasons as well as weight loss. ${ }^{23}$ Word of mouth by link workers or members of the community were the most popular methods of engagement. ${ }^{23}$ Prioritising the needs of families and a reluctance to walk to classes were barriers to attending group classes.

Exercise was popular, and women who had a large body mass index were more likely to want the intervention to continue. ${ }^{23}$ Participants wanted to keep materials such as audiotapes and flashcards following the interventions to use afterwards. ${ }^{24}$ Participants particularly valued the role of South Asian bilingual link workers and interpreters within programmes. ${ }^{23,24}$ One study anecdotally reported that changes were adopted by others in the community. ${ }^{22}$

\section{DISCUSSION}

Summary

Only four studies, all specifically involving South Asian communities alone, met eligibility criteria. Lack of controls in three, as well as inconsistency in measures and outcomes, meant it was not possible to pool data in a meta-analysis; as a result of this, firm conclusions about the effectiveness of the interventions that were assessed cannot be made. However, several insights and common themes can be offered from this review to inform future intervention development and research.

In relation to clinical outcomes, all programmes with combined physical activity and dietary change components reported decreases in weight where measured, but where the results were analysed by sex, changes in weight, waist circumference, and body and abdominal 
Table 4. Psychological and knowledge-based outcomes and acceptability of included studies

\begin{tabular}{|c|c|c|c|c|c|c|}
\hline Author, year & Intervention & $\begin{array}{l}\text { Outcome } \\
\text { measure }\end{array}$ & $\begin{array}{l}\text { Participants } \\
\text { analysed }\end{array}$ & Results & Acceptability & Notes \\
\hline Mathews et al ${ }^{21}$ & $\begin{array}{l}\text { Health clinic } \\
\text { one-to-one CHD } \\
\text { service with optional } \\
\text { community activities }\end{array}$ & $\begin{array}{l}\text { Psychological } \\
\text { motivational stage of } \\
\text { change in relation to } \\
\text { CHD and diabetes control } \\
\text { (precontemplation/ } \\
\text { contemplation/ } \\
\text { preparation/action/ } \\
\text { maintenance) }\end{array}$ & 137 & $\begin{array}{l}\text { Psychological } \\
\text { motivational stage } \\
\text { (a) \% increased motivational } \\
\text { stage: }+50 \\
\text { (b) } \% \text { decreased motivational } \\
\text { stage: }-21 \\
\text { (c) } \% \text { showed no change: } 29\end{array}$ & $\begin{array}{l}\text { Qualitative research showed } \\
\text { the project was highly valued, } \\
\text { reported elsewhere }\end{array}$ & $\mathrm{N} / \mathrm{A}$ \\
\hline Rush et al ${ }^{22}$ & $\begin{array}{l}\text { Group physical } \\
\text { activity and diet } \\
\text { education sessions }\end{array}$ & N/A & $\begin{array}{l}20 \text { female } \\
21 \text { male }\end{array}$ & N/A & $\begin{array}{l}\text { Anecdotally reported that } \\
\text { changes were adopted by } \\
\text { others in the community } \\
\text { group and wider families }\end{array}$ & N/A \\
\hline $\begin{array}{l}\text { Williams and } \\
\text { Sultan }^{23}\end{array}$ & $\begin{array}{l}\text { Group healthy- } \\
\text { eating and exercise } \\
\text { classes }\end{array}$ & N/A & 13 & (1) & $\begin{array}{l}\text { Nine women recommended } \\
\text { the group to friends. Link } \\
\text { worker and word of mouth } \\
\text { were the most frequent } \\
\text { recruitment methods. } \\
\text { Women attended for weight } \\
\text { loss and social reasons. } \\
\text { Barriers to attendance } \\
\text { included reluctance to walk } \\
\text { to the group (winter months } \\
\text { time, fear of walking alone) } \\
\text { and prioritising the needs of } \\
\text { other family members. } \\
\text { Exercise was a popular aspect } \\
\text { of group. Those with higher } \\
\text { BMls were more likely to say } \\
\text { they would reattend. The } \\
\text { bilingual link worker was } \\
\text { particularly valued as seven of } \\
\text { the } 13 \text { women wished to be } \\
\text { interviewed in their own languag }\end{array}$ & ( \\
\hline $\begin{array}{l}\text { Hawthorne and } \\
\text { Tomlinson }{ }^{24}\end{array}$ & $\begin{array}{l}\text { Flashcard, one- } \\
\text { to-one diabetes } \\
\text { health education }\end{array}$ & $\begin{array}{l}\frac{\text { Psychological }}{\text { (1) finds it hard to refuse }} \\
\text { food at social events (\%) } \\
\text { (2) can choose correct } \\
\text { food at weddings }(\%) \\
\text { Knowledge } \\
\text { (1) agrees importance of } \\
\text { diet to diabetes } \\
\text { prevention (\%) } \\
\text { (2) correctly identifies } \\
\text { different food values }(\%)\end{array}$ & $\begin{array}{l}106 \\
\text { interventions } \\
86 \text { controls }\end{array}$ & $\begin{array}{l}\text { Psychological } \\
\text { (1) finds it hard to refuse food at } \\
\text { social events: \% change } \\
\text { intervention group: + } 10, \\
\text { baseline } 73, \% \text { change control } \\
\text { group: }+5, \text { baseline } 69 \\
\text { (2) can choose correct food at } \\
\text { weddings: \% change intervention } \\
\text { group: }+14, \text { baseline } 64 \% \% \text { change } \\
\text { control group: }-1.9, \text { baseline } 63 \\
\text { Knowledge } \\
\text { (1) agrees the importance of diet } \\
\text { to diabetes prevention: } \% \text { change } \\
\text { intervention group: }+20, \text { baseline } 74 \\
\% \text { change control group: }+6, \\
\text { baseline } 76 \\
\text { (2) correctly identifies different } \\
\text { food values: } \% \text { change intervention } \\
\text { group: }+20 \text { (ANOVA-adjusted } \\
\text { pre-post difference } 11.8 \text { ) baseline } \\
51, \% \text { change control group }+1.5, \\
\text { baseline } 58\end{array}$ & $\begin{array}{l}\text { Most participants rated the } \\
\text { intervention positively, liked } \\
\text { the bilingual link worker's } \\
\text { sensitive approach, valued } \\
\text { the information, and felt } \\
\text { empowered to control diabetes. } \\
\text { Two patients wanted videos } \\
\text { or audiotapes; some wanted } \\
\text { to keep the flashcards to use } \\
\text { when shopping }\end{array}$ & $\begin{array}{l}\text { Details of 'different } \\
\text { food values' not } \\
\text { reported } \\
P \text {-values not } \\
\text { reported }\end{array}$ \\
\hline
\end{tabular}

${ }^{a} P<0.01 . C H D=$ coronary heart disease. $N / A=$ not applicable.

fat, these were only significant for men.22 The sex difference could relate to South Asian women from a variety of religious backgrounds being deterred from attending mixed-sex activities ${ }^{27}$ but, as programme engagement data were not provided, this 
cannot be ascertained. Mixed results were found for other clinical outcomes, with some reduction in blood pressure and blood lipid profiles, but no improvement, for example. in insulin sensitivity or resistance.

Participants in one study appeared to change dietary and activity patterns, but reliability of these behavioural outcomes was limited by use of single-item measures and self-reporting. Support for the efficacy of improving dietary knowledge was weak and no study measured knowledge of physical activity. One study suggested its community-based programme may encourage participants to progress through motivational stages of change, ${ }^{21}$ but this was reported in relation to general risk rather than specific behaviours.

\section{Factors contributing to intervention engagement and acceptability}

The involvement of trained bilingual community link workers appeared key to enhancing intervention acceptability and delivery in those studies that involved participants who were socially disadvantaged; for example, those from Pakistani and Bangladeshi communities, with significant proportions of participants across studies speaking little or no English. 23,24 Qualitative feedback confirmed that, in addition to language skills, link workers were valued for their sensitivity and cultural understanding, which may have facilitated more meaningful and personal engagement in programmes. This finding is consistent with previous research suggesting that establishing relationships is important to the receptivity of lifestyle interventions in primary care..$^{28}$

Programmes that were also promoted in the community and recruited by word of mouth appeared to generate more positive outcomes than those initiated from more formal healthcare settings, such as hospitals or clinics. Generating interest through local-community resources appeared to be beneficial due to the familiarity of the setting and the informal, social element of the meetings. ${ }^{23}$

Most programmes offered some form of personalised feedback, either in the form of one-to-one consultations or measurements of individual progress. This approach seemed to be potentially promising when accompanied by visual aids and handouts. ${ }^{21}$ Pictures and other visual aids were also valued and may help to overcome language and literacy barriers. ${ }^{22}$

\section{Implications for research and practice} Many intervention studies that were identified had, or may have, included South Asian participants who were historically immigrant, but experiences that were distinguishable for South Asian individuals were not reported; as a result, only four studies met review criteria. Potentially important insights for enhancing appropriateness and implementation of interventions may be missed if relevant data are not reported when South Asian individuals are part of study populations. In addition to outcomes, information about participants' engagement, language abilities, and social demographic, including deprivation and education status, may enable assessment of relevance and transferability. This is particularly pertinent for those South Asian communities that are more disadvantaged and at higher risk, where effective interventions are most needed and evidence is lacking. ${ }^{17}$

Three of the four studies reviewed appeared to have benefited from some prior qualitative work with target communities to inform intervention components; this may have been important to enhancing their acceptability. ${ }^{17,29}$ However, the quality of outcome data in the studies reviewed was generally poor, with a failure to consider potential confounders or adverse effects, and a lack of formal statistical-significance testing. All studies had flaws in internal validity, due to a lack of concurrent controls and data concerning programme compliance. Another common problem was a lack of standardised measures, particularly for behavioural, psychological, and knowledge-based outcomes. The majority of these measures lacked clear definition and appeared to be purpose designed, with no data available on piloting outcomes, validity, or reliability. Where possible, objective measures of behaviour, using standardised scales that have been validated in South Asian populations, are needed alongside clinical measures, as maintained behaviour change is necessary for sustained clinical benefit

The importance of theoretical frameworks for evaluating complex interventions is increasingly recognised, ${ }^{29}$ but none of the studies designed their intervention with this in mind. Improving the effectiveness of lifestyle interventions requires an understanding of the causal techniques and procedures responsible for change. ${ }^{30}$ In the absence of a clear evidence base, progress is likely to be slow, with 'wheels' being reinvented rather than reapplied. All studies but one failed to measure the motivation of participants to change their lifestyles, which may account for the relative lack 
of intervention effects. Greater emphasis on combining targeted information with appropriate motivational techniques and specific behavioural guidance is needed. In addition, interventions may have been time and resource intensive in these studies, but no economic evaluation data were provided.

This review highlights a dearth of wellevaluated, community-based, physical activity, and dietary interventions for South Asian populations. Nevertheless, programmes were well received, suggesting that the potential to enhance physical activity and promote dietary change in these communities is considerable. Interventions that were reviewed may have resulted in some initial effects on health outcomes and offer useful first steps for enhancing health promotion in this group, which is at high risk of developing chronic disease. However, there remains much to be done to impact disease risk or morbidity, given the sustained and highly intensive interventions necessary to achieve this in other populations that are at risk. 9.10,13

Further research should focus on developing interventions that:
- are informed by prior qualitative work with target communities;

- incorporate a theoretical framework;

- employ a robust methodology, with standardised and objective measures;

- target education and behavioural motivation; and

- provide a comparison group to assess effectiveness when naturally occurring change is controlled.

Approaches, particularly for South Asian populations that are socio-educationally deprived, may usefully build on current experience by using community-based programmes in a familiar environment with trained, bilingual community link workers. Interventions that include feedback and audiovisual media seem to be well received. Health-economic analyses should be performed alongside future experimental studies to ensure that promising preventative health programmes in these high-risk groups are cost effective and can be feasibly implemented. 


\section{REFERENCES}

1. Bhopal R. Epidemic of cardiovascular disease in South Asians. BMJ 2002 324(7338): 625-626.

2. Mather HM, Chaturvedi N, Fuller JH. Mortality and morbidity from diabetes in South-Asians and Europeans: 11 year follow-up of the Southall Diabetes Survey London, UK. Diabetic Med 1998; 15(1): 53-59.

3. Chowdhury T, Lasker S, Mahfuz R. Ethnic differences in control of cardiovascular risk factors in patients with type 2 diabetes attending an Inner London diabetes clinic. Postgrad Med J 2006; 82(965): 211-215.

4. Department of Health. NHS East Midlands: From Evidence to Excellence, Our Clinical Vision for Patient Care; 2008.

5. Abate N, Chandalia M. The impact of ethnicity on type 2 diabetes. J Diabetes Complicat 2003; 17(1): 39-58.

6. Chambers JC, Kooner JS. Diabetes, insulin resistance and vascular disease among Indian Asians and Europeans. Semin Vasc Med 2002; 2(2): 199-214.

7. Hussain A, Claussen B, Ramachandran A, Williams R. Prevention of type 2 diabetes: a review. Diabetes Res Clin Pr 2007; 76(3): 317-326.

8. Yang $Q$, Cogswell M, Flanders D, et al. Trends in cardiovascular health metrics and associations with all-cause and CVD mortality among US adults. JAMA 2012; 307(12): 1273-1283

9. Li G, Zhang P, Wang J, et al. The long-term effect of lifestyle interventions to prevent diabetes in the China Da Qing Diabetes Prevention Study: a 20 -year follow-up study. Lancet 2008; 371(9626): 1783-1789.

10. Lindstrom J, Ilanne-Parikka P, Peltonen $M$, et al. Sustained reduction in the incidence of type 2 diabetes by lifestyle intervention: follow-up of the Finnish Diabetes Prevention Study. Lancet 2006; 368(9548): 1673-1679.

11. Norris SL, Zhang $X$, Avenell $A$, et al. Long-term effectiveness of weight-loss interventions in adults with pre-diabetes: a review. Am J Prev Med 2005; 28(1): 126-139.

12. Mente A, de Koning L, Shannon $\mathrm{H}$, et al. A systematic review of the evidence supporting a causal link between dietary factors and coronary heart disease. Arch Int Med 2009; 169(7): 659-669.

13. Gillies CL, Abrams KR, Lambert PC, et al. Pharmacological and lifestyle interventions to prevent or delay type 2 diabetes in people with impaired glucose tolerance: systematic review and meta-analysis. BMJ 2007; 334(7588): 299.

14. Fischbacher CM, Hunt S, Alexander L. How physically active are South Asians in the United Kingdom? A literature review. J Pub Health 2004; 26(3): 250-258.

15. Justin M, Jemni M. South Asians, physical exercise and heart disease. Heart 2011; 97(8): 607-609.
16. Misra A, Alappan NK, Vikram NK, et al. Effect of supervised progressive resistance-exercise training protocol on insulin sensitivity, glycemia, lipids, and body composition in Asian Indians with type 2 diabetes. Diabetes Care 2008; 31(7): 1282-1287.

17. National Institute for Health and Clinical Excellence. Preventing type 2 diabetes: population and community-level interventions in high-risk groups and the general population. NICE public health guidance 35. London: DoH, 2011.

18. Kirkham J, Altman D, Williamson P. Bias due to changes in specified outcomes during the systematic review process. PLoS One 2010; 5(3): e9810.

19. Downs S, Black N. The feasibility of creating a checklist for the assessment of the methodological quality of both randomised and non-randomised studies of health care interventions. J Epidemiol Commun Health 1998; 52(6): 377-384.

20. Petticrew P, Roberts H. Systematic reviews in the social sciences: a practical guide. Oxford: Blackwell Publishing, 2006.

21. Mathews G, Alexander J, Rahemtulla T, et al. Impact of a cardiovascular risk control project for South Asians (Khush Dil) on motivation, behaviour, obesity, blood pressure and lipids. J Pub Health (Oxf) 2007; 29(4): 388-397.

22. Rush E, Chandu V, Plank L. Reduction of abdominal fat and chronic disease factors by lifestyle change in migrant Asian Indians older than 50 years. Asia Pac J Clin Nutr 2007; 16(4): 671-676.

23. Williams J, Sultan M. Evaluation of a Asian women's healthy eating and exercise group. J Hum Nutr Diet 1999; 12: 91-98.

24. Hawthorne K, Tomlinson S. One-to-one teaching with pictures-flashcard health education for British Asians with diabetes. Br J Gen Pract 1997; 47(418): 301-304

25. Prochaska, JO, DiClemente CC. Stages and processes of self-change of smoking: Toward an integrative model of change. J Consult Clin Psychol 1983; 51(3): 390-395

26. Netto G, McCloughan I, Bhatnagar A. Effective heart disease prevention: lessons from a qualitative study of user perspectives in Bangladeshi, Indian and Pakistani communities. Public Health 2007; 121(3): 177-186.

27. Sriskantharajah J, Kai J. Promoting physical activity among South Asian women with coronary heart disease and diabetes: what might help? Family Practice 2007; 24(1): 71-76.

28. Whittemore R, Melkus G, Wagner J, et al. Translating the diabetes prevention program to primary care. Nurs Res 2009; 58(1): 2-12.

29. Medical Research Council. A framework for development and evaluation of RCTs for complex interventions to improve health. London: MRC, 2000.

30. Michie S, Abraham C. Interventions to change health behaviours: evidencebased or evidence-inspired? Psychol Health 2004; 19(1): 29-49. 